\title{
LITTLE ICE AGE GLACIAL GEOMORPHOLOGY AND SEDIMENTOLOGY OF PORTAGE GLACIER, SOUTH-CENTRAL ALASKA
}

\author{
JOÃO SANTOS ${ }^{1}$ \\ CARLOS CORDOVA ${ }^{2}$
}

\begin{abstract}
The study of glacial landforms and deposits is important, as it is difficult to observe processes under modern glaciers and ice-sheets. Thus landscapes and sediments that are the product of present glaciation can give insight into processes that occurred during Pleistocene times. This study investigates the genesis of little ice age glacial landforms present in Portage Glacier, South-Central Alaska. The present day moraine morphology and sedimentology in Portage Glacier valley reveals the presence of two types of till and moraines. The clast-rich sandy diamicton present on the 1852 moraine is interpreted to be a basal till indicating this feature is a push moraine representing an advance or a standstill position of Portage Glacier in 1852. The moderately sorted gray sandy boulder gravel present on the 1900 and 1922 moraines is interpreted to be an ice-marginal deposit (ablation till) with a mixture of supraglacial and glaciofluvial sediments deposited by slumping and stream sorting processes. All of these features are interpreted to be ablation moraines representing glacier retreat and moraine building in 1900 and 1922.
\end{abstract}

Key words: Glacial geomorphology, Portage Glacier, South-Central Alaska.

Resumo - Testemunhos da Pequena idade Glaciária. Geomorfologia e Sedimentologia no Glaciar Portage (Centro-Sul do Alasca). O estudo das formas e dos depósitos glaciários é muito importante, dada a dificuldade de observação dos processos que ocorrem na base de glaciares modernos. As paisagens e os sedimentos devidos aos glaciares actuais são elementos-chave na compreensão dos processos plistocénicos. Este estudo dirige-se à génese das formas glaciárias da Pequena Idade do Gelo do Glaciar de Portage, situado no Centro - Sul do Alasca. A morfologia e a sedimentologia das suas moreias revelam a existência de dois tipos de till e de moreia. O diamicton arenoso, rico em calhaus angulosos, presente na moreia de 1852 é interpretado como um till subglaciário, indicando que ela é uma moreia de progressão e que representa o avanço do Glaciar Portage na referida data. As areias e calhaus moderadamente calibrados, presentes nas moreias de 1900 e 1922, são consideradas um till de fusão supraglaciário, com uma mistura de sedimentos supraglaciários e

Recebido: 15/11/2007. Revisto: 11/06/2009. Aceite: 19/06/2009.

1 University of Coimbra, Department of Geography. E-mail: jsantos@kent.edu

2 Oklahoma State University, Department of Geography. E-mail: cordova@okstate.edu 
fluvioglaciários, depositados por movimentos de deslizamento e por escoamento fluvial. Estas duas formas são interpretadas como moreias de ablação e representam os retrocessos glaciários de 1900 e de 1922.

Palavras-chave: Geomorfologia glaciária, glaciar de Portage, Centro-Sul do Alasca.

Resumé - Le PETIT ÂGe Glaciaire. GÉOMORPHOlogie ET SÉdimentologie DU glacier de Portage, Centre sud de l'Alaska. L'étude des formes et des dépôts glaciaires est d'autant plus importante qu'il est difficile d'observer les processus en cours sous les glaciers actuels. Quant aux paysages et sédiments produits par les glaciers actuels, ils permettent de comprendre les processus datant du Pléistocène. Cette étude analyse la genèse des formes datant du Petit Âge Glaciaire dans le glacier de Portage. La morphologie et la sédimentologie de ses moraines montrent l'existence de deux types de till et de moraine Un diamicton sableux, riche en cailloux anguleux, présent dans la moraine de 1852, est interprété comme étant un till subglaciaire, ce qui veut dire qu'il s'agit d'une moraine de progression, datant d'une avancée du glacier en 1852. Les sables et cailloux plus ou moins calibrés, présents dans les moraines de 1900 et 1922, sont interprétés comme un till de fusion supraglaciaire, mêlé à des sédiments supraglaciaires et fluvioglaciaires, déposés lors de glissements et par écoulement fluvial. Ces deux formations sont interprétées comme des moraines de fusion, liées aux reculs glaciaires de 1900 et 1922 .

Mots-clés: Géomorphologie glaciaire, glacier de Portage, Centre sud de l'Alaska.

\section{INTRODUCTION}

The study of glacial landforms and deposits is important, as it is difficult to observe processes under modern glaciers and ice-sheets. Thus landscapes and sediments that are the product of present glaciation can give insight into processes that occurred during Pleistocene times (Benn, 1994; Benn and Evans, 1998).

This study investigates the genesis of Little Ice-Age (LIA) glacial and ice-contact landforms present in Portage Glacier, in south-central Alaska based on geomorphic and sedimentologic observations. Geomorphic research has been done in the Portage Glacier area by Crossen $(1990,1992)$, but these studies have focused heavily on the reconstruction of the LIA history of Portage Glacier, using dendrochronologic and lichenometric dating techniques. Until present time no work has been done on the genesis, geomorphology, and sedimentology of these glacial landforms. Therefore, to gain a better understanding of the array of processes responsible for the genesis of these features, this research will consist of a detailed geomorphic study of these landforms and a sedimentologic study of the fabrics in order to contribute for reconstructing the paleo-process history of this temperate valley glacier.

\section{STUDY SITE AND PREVIOUS WORK}

Portage glacier and Portage lake forefields were the study areas chosen for this research. Portage glacier is a valley glacier with an ice tongue approximately $7 \mathrm{~km}$ long 
and $1.6 \mathrm{~km}$ wide. It is fed by ice from the Blackstone-Spencer ice complex and from several local cirques both situated in the Gulf of Alaska region (fig. 1). Research on Portage glacier was conducted on moraines and ice-contact features present in the glacier's fore field that were deposited since 1852 until the present time (fig. 2).

Identification of the positions of Portage glacier during the LIA were primarily the work of Tarr and Martin (1914) and Field (1975) who visited, photographed, and mapped Portage Glacier position during the LIA. Latter, Crossen $(1990,1992)$ presented the first numeric dated reconstruction of the Little Ice Age history of Portage glacier based on dendrochronology and lichenometric techniques.

Based on Crossen $(1990,1992)$, the LIA history of Portage glacier seems to be correlative to other LIA histories of other Alaskan valley and tidewater glaciers (Calkin et al., 2001; Wiles, 1994; Wiles et al., 1999a; Wiles et al., 1999b). According to Crossen (1990, 1992), Portage Glacier advanced to its terminal position in Portage Valley sometime prior to 1810 A.D and the retreat from its LIA maximum started in 1852 when the glacier built its terminal moraine. After retreat from its 1852 terminal moraine the Portage Glacier built a proglacial lake that facilitated fast retreat due to calving (Seramur et al., 1997). Further recessional stages occurred in 1900, 1922 and 1984 when the glacier built three recessional moraines.

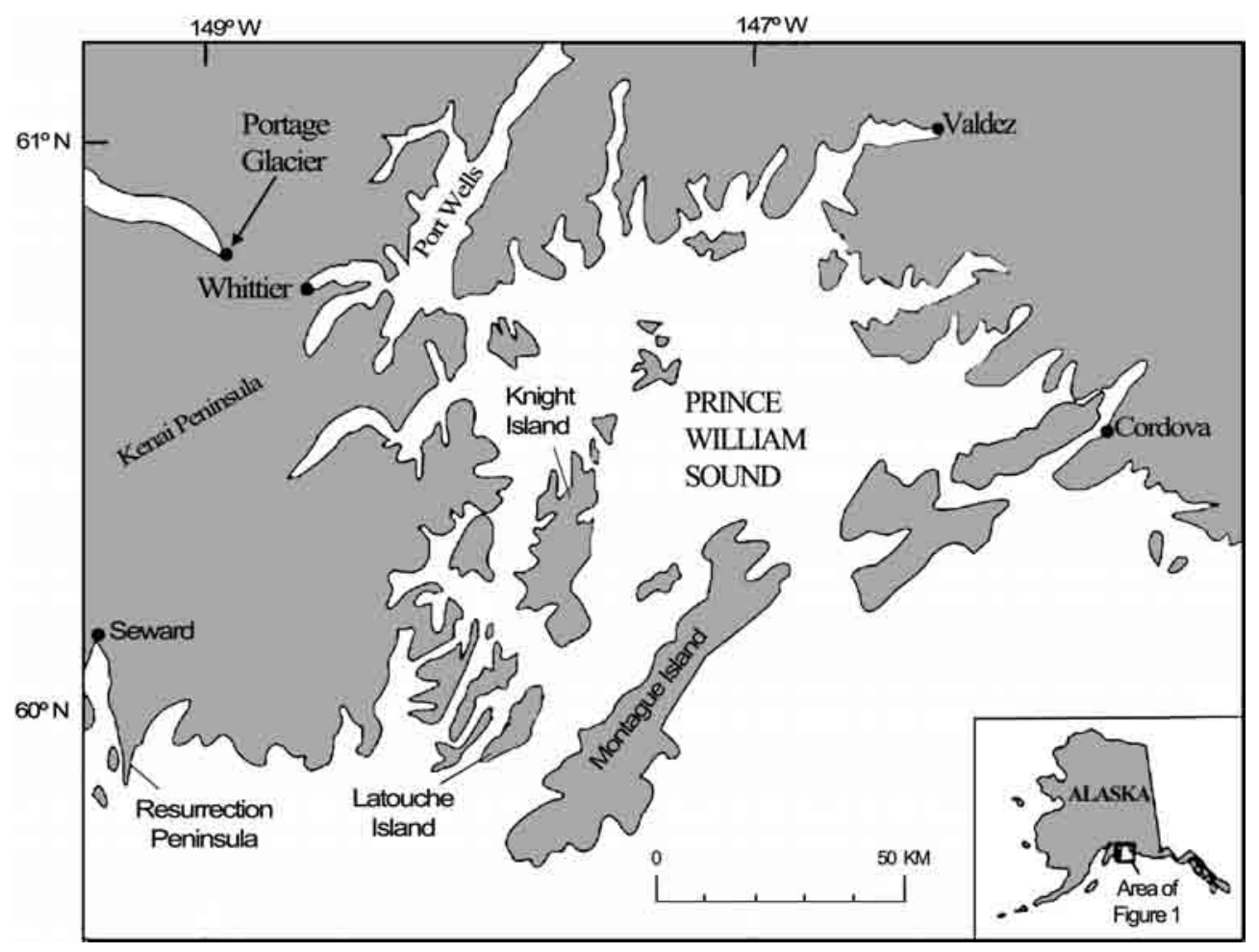

Fig. 1 - Location of the study area.

Fig. 1 - Localização da área de estudo. 


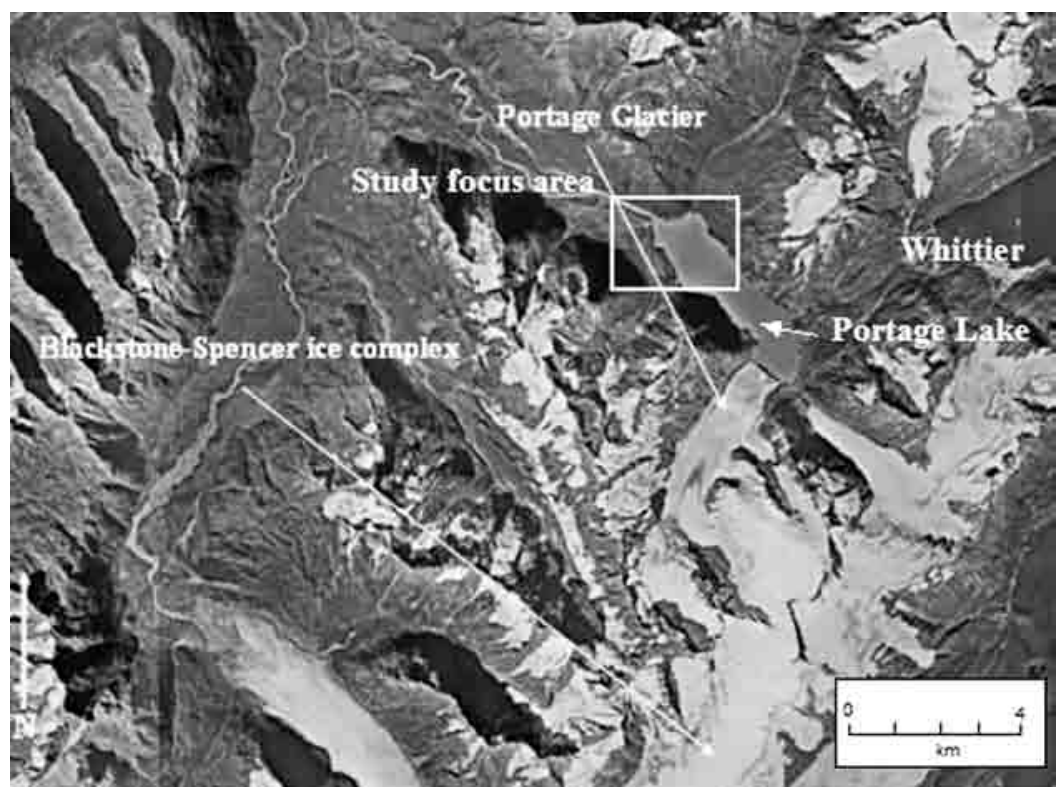

Fig. 2 - Aerial photograph of Portage Glacier and the Blackstone-Spencer ice complex (http://terraserver.com/).

Fig. 2 - Fotografia aérea do Glaciar de Portage e do complexo glaciário de Blackstone-Spencer.

\section{METHODOLOGY}

The Portage Glacier valley contains an array of landforms that are important for understanding the palaeo-ice processes and dynamics that contributed to their formation. Three dated moraines (1852, 1900 and 1922) where chosen for this research (fig. 3). Reconstruction of the processes responsible for the genesis of these features was accomplished in the summers of 2002 and 2005, using geomorphic and sedimentologic techniques. These features were identified by type, shape, size, orientation and slope, using aerial and ground photographs.

Their sedimentology was analyzed through the use of till fabric (Mark, 1973; Dowdeswell and Sharp, 1986; Benn, 1994) and grain size analysis techniques (Folk, 1955, 1966; Udden, 1898; Wentworth, 1922; Krumbein, 1934; Nichols, 1999). At least two samples for grain size analysis were collected per moraine from exposures dug on these features. At least one pebble-fabric analysis per moraine (excluding the 1984 moraine) was conducted by measuring the long axis of twenty-five elongated pebbles. These were used mainly to reconstruct approximate palaeo-ice flow conditions during deposition and to determine till type and sediment sorting and provenance. 


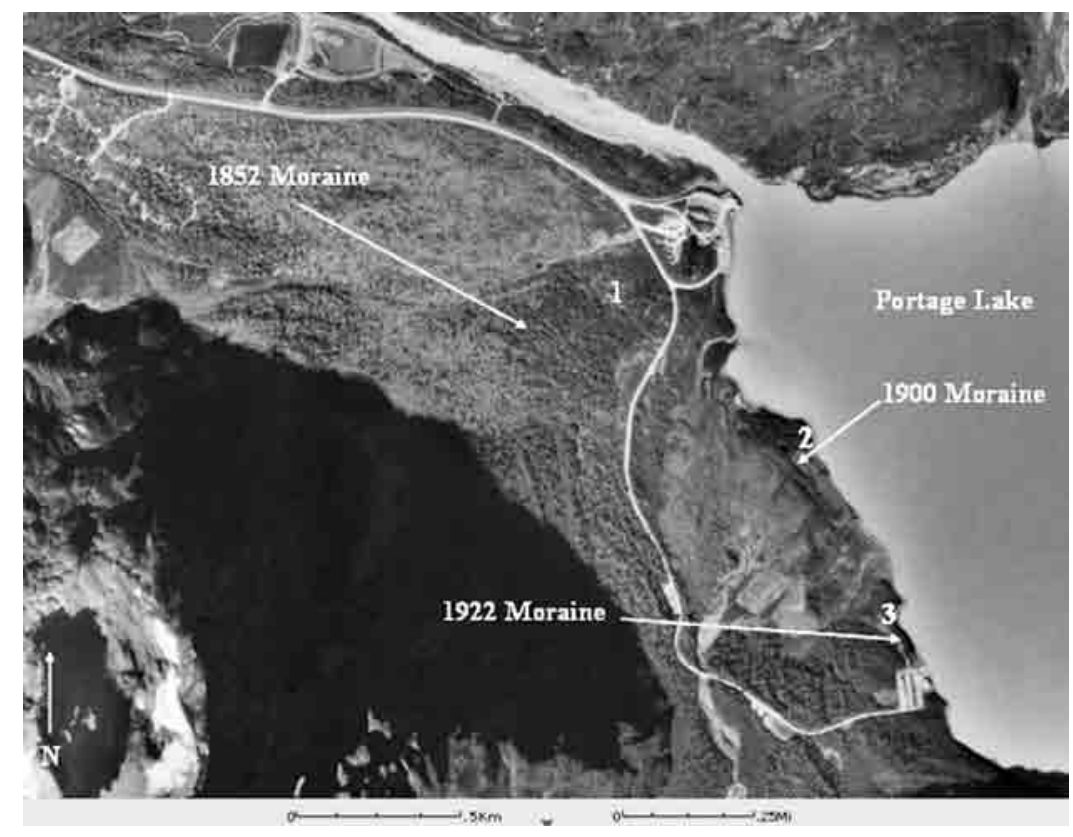

Fig. 3 - Vertical aerial photograph of the research area showing moraines and location of exposures for sampling (www.terraserver.com).

Fig. 3 - Fotografia aérea vertical da área de estudo: moreias e locais de amostragem.

\section{GEOMORPHOLOGY AND SEDIMENTOLOGY OF LIA MORAINES}

Lateral, medial, recessional, push and terminal moraines are common features in Portage Valley. They are the product of ice recession and advance that occurred from 1810 until present time. All of these features have different orientations. End and recessional moraines have a southwest-northeast orientation and are perpendicular to ice flow. Lateral and medial moraines have a southeast-northwest orientation and are parallel to the ice flow direction in Portage Valley. The shape of these moraines is similar. They have sharp crests with steep slopes showing that they are very recent. Recessional moraines such as the ones deposited in 1900 and 1922 are the smallest features in Portage Valley. They represent short periods of standstill or ice retreat. This type of glacial regime allowed small deposition of morainal deposits. In contrast terminal moraines such as the 1852 moraine are the largest features present in this area. In contrast to recessional moraines these features are larger and they generally represent longer periods of deposition and moraine building. 


\section{The 1852 Terminal Moraine}

This is the largest feature in Portage Valley. It is approximately 48 meters high with sharp crests and steep slopes, and a southwest-northeast orientation that is perpendicular to ice flow in Portage Valley (fig. 3). Like any other end or terminal moraines present in glaciers it has a curvilinear form (Easterbook, 1999), reflecting the shape of Portage Glacier as it started to retreat from its LIA maximum. Hummocky topography is expressed in this moraine which seems to be good evidence that after 1852 the ice front of Portage Glacier must have became stagnant and started its LIA retreat.

The 1852 dated moraine (fig. 4) is mainly composed of a massive poorly sorted gray clast-rich fine sand diamiction with modal grain sizes classes of $3.5 \phi$ to $4.0 \phi$ for the fine sand and $-1.0 \phi$ to $-0.5 \phi$ for the gravel with a polymodal distribution (fig. 5). Clasts in the samples are striated, sub-rounded to sub-angular, and well-oriented. The main orientation is towards northwest showing that ice that built the 1852 moraine was coming from the south-east (fig. 6).

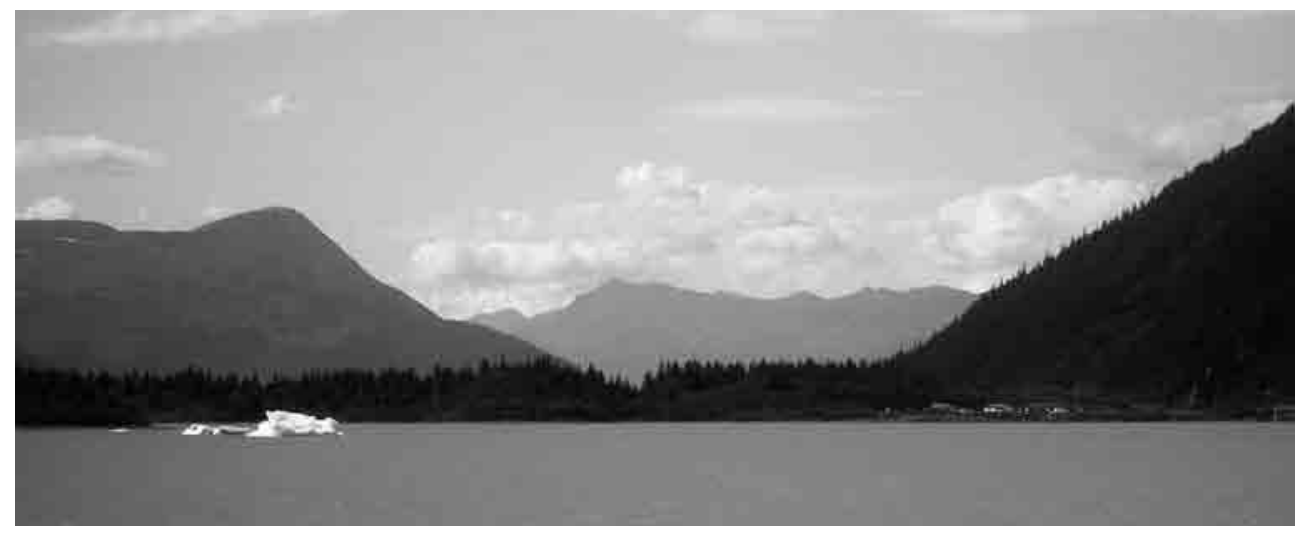

Fig. 4 - Portage Glacier 1852 terminal moraine Fig. 4 - Moreia terminal do Glaciar Portage de 1852 


\section{Sample \#1}
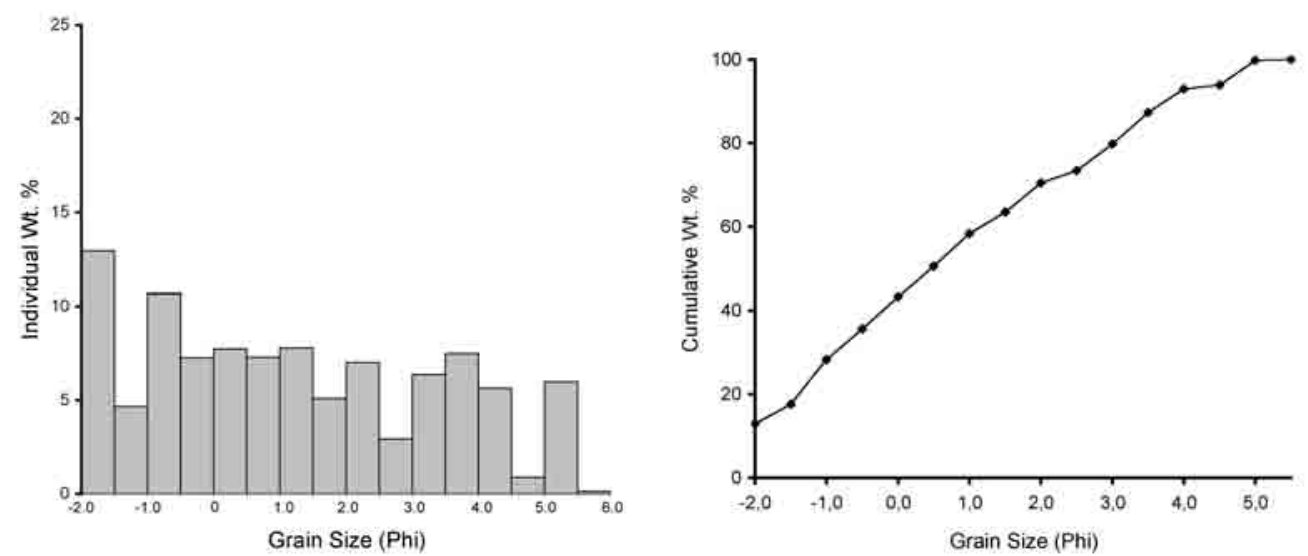

Sample \#2
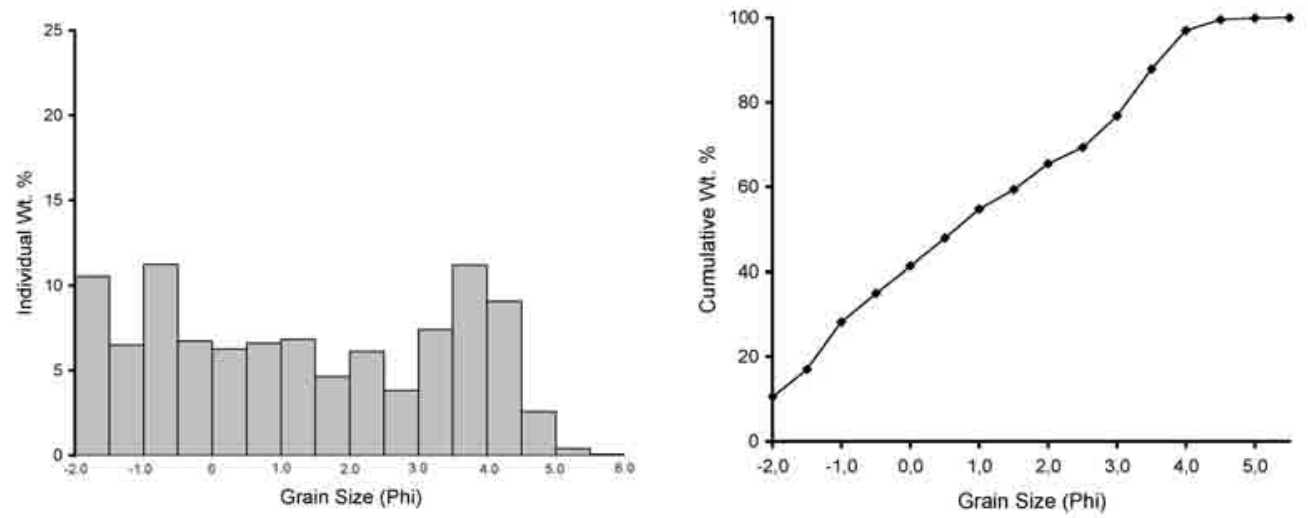

Fig. 5 - Grain size distribution of the 1852 moraine. Exposure 1, Unit 1 samples 1 and 2.

Fig. 5 -Distribuição granulométrica na moreia de 1852.

Corte 1,Unidade 1 amostras 1 e 2. 


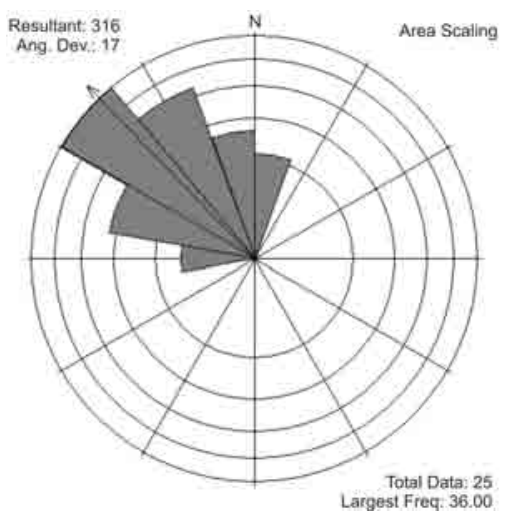

Fig. 6 - Clast orientations in the 1852 moraine. Exposure 1, sample 1. Fig. 6 - Orientação dos clastos na moreia de 1852. Corte 1, amostra 1.

\section{The 1900 Moraine}

The 1900 moraine (fig. 7) is a small feature in Portage Valley. It is approximately 33 meters high with sharp crests and steep slopes. It has a southeast-northwest orientation and is parallel to ice flow in Portage Valley (fig. 3). Contrary to the 1852 moraine, hummocky topography and kettle lakes are absent on this feature. The 1900 dated moraine is mainly composed of moderately sorted gray sandy boulder gravel with a modal grain size class of $-1.0 \phi$ to $-0.5 \phi$ for the sandy boulder gravel with a unimodal distribution (fig. 8). Clasts in the samples are sub-rounded to sub-angular, and lack a defined preferred orientation (fig. 9).

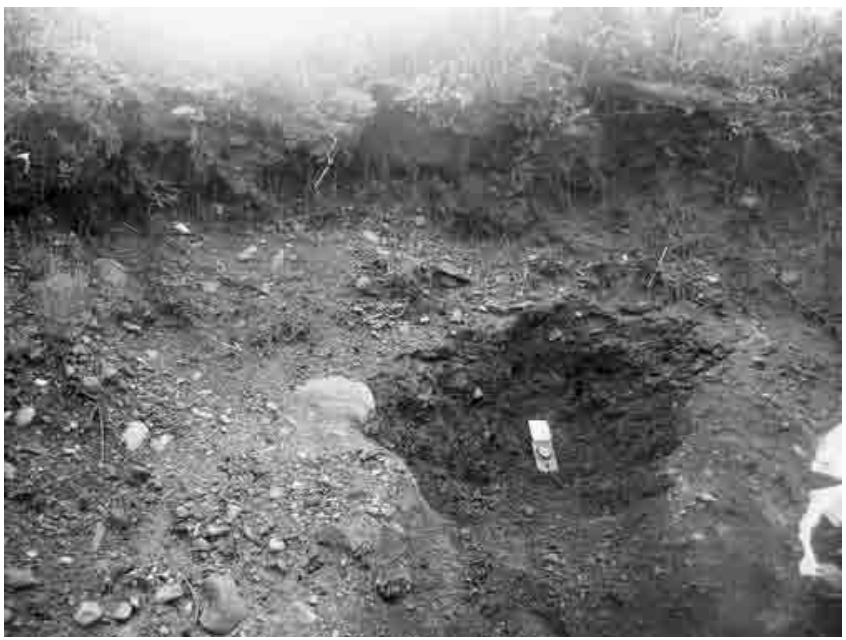

Fig. 7 - The 1900 Moraine dugout Exposure.

Fig. 7 - Local de amostragem na moreia de 1900. 


\section{Sample \#1}
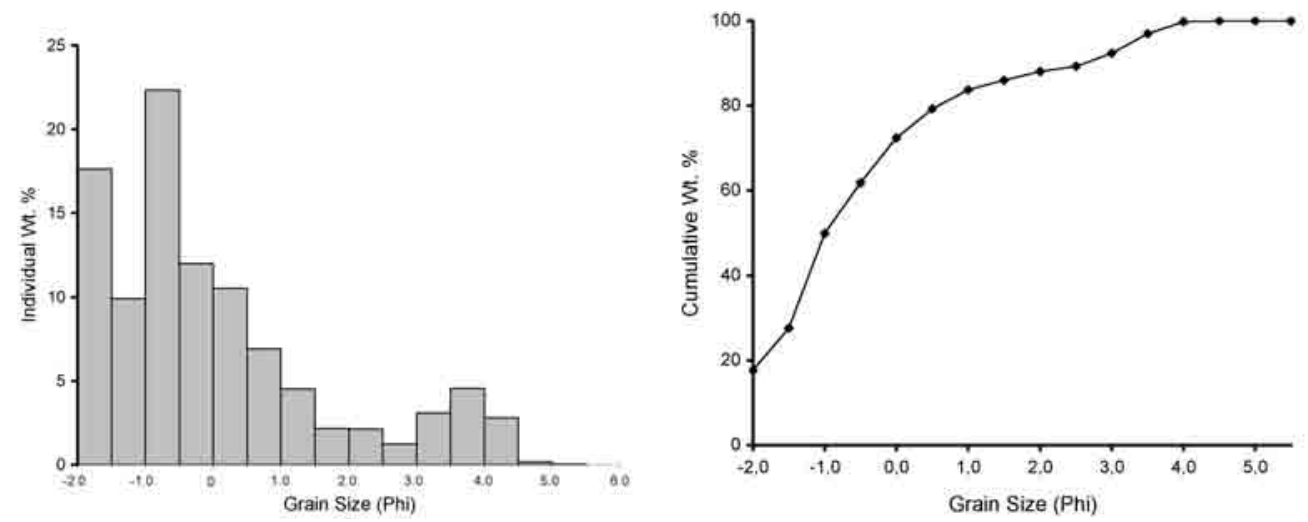

Sample \#2
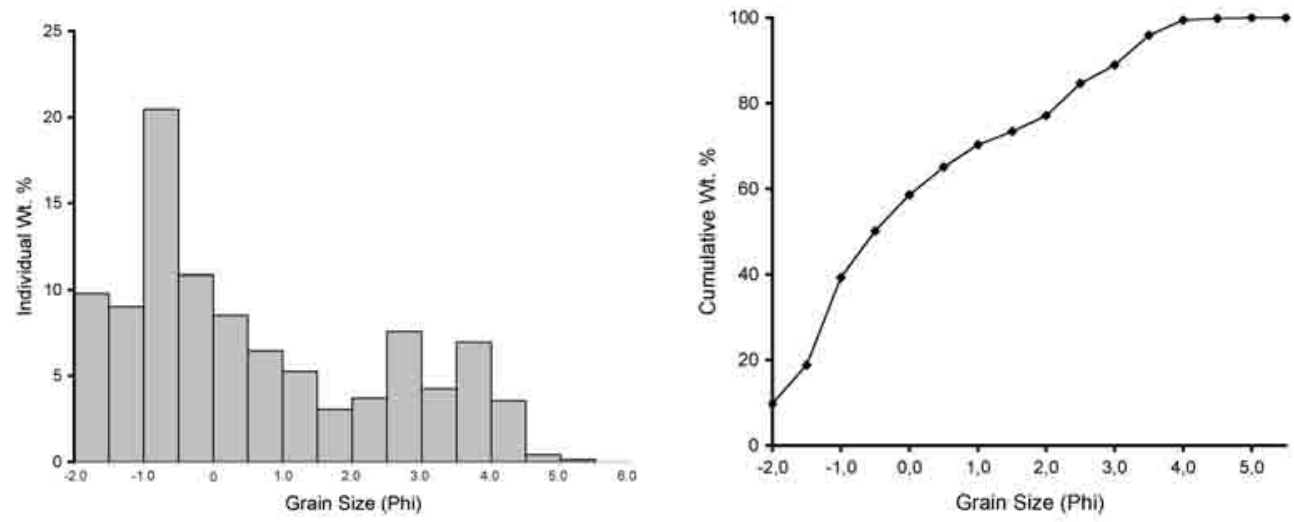

Fig. 8 - Grain size distributions of the 1900 moraine. Exposure 1, Unit 1 samples 1 and 2.

Fig. 8 -Distribuição granulométrica na moreia de 1900.

Corte 1, Unidade 1 amostras 1 e 2. 


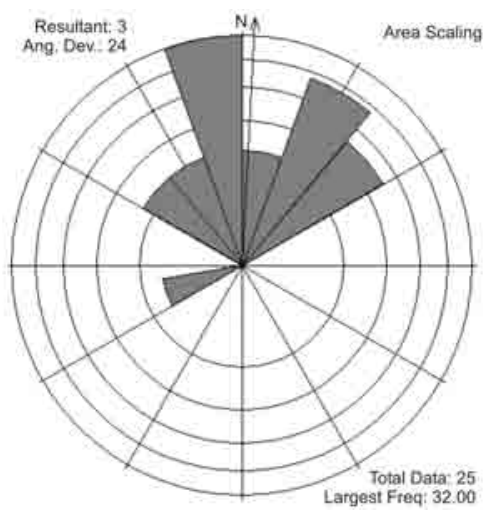

Fig. 9 - Clast orientations in the 1900 moraine. Exposure 1, Sample 1. Fig. 9 - Orientação dos clastos na moreia de 1852. Corte 1, amostra 1.

\section{The 1922 Moraine}

The 1922 moraine is also a small feature (fig. 10). It is approximately 30 meters high and has sharp crests and steep slopes. Like the 1900 moraine described previously it has a southeast-northwest orientation, which is parallel to ice flow in Portage Valley (fig. 3). Contrary to the 1852 moraine and similar to the 1900 moraine, hummocky topography is absent on this feature. The 1922 moraine is very similar to the 1900 moraine in sediment composition. It is mainly composed of moderately sorted gray sandy boulder gravel with a modal grain size class of $-1.0 \phi$ to $-0.5 \phi$ for the sandy boulder gravel with a unimodal distribution (fig. 11). Clasts in the samples are subrounded to sub-angular, and lack a defined preferred orientation (fig. 12).

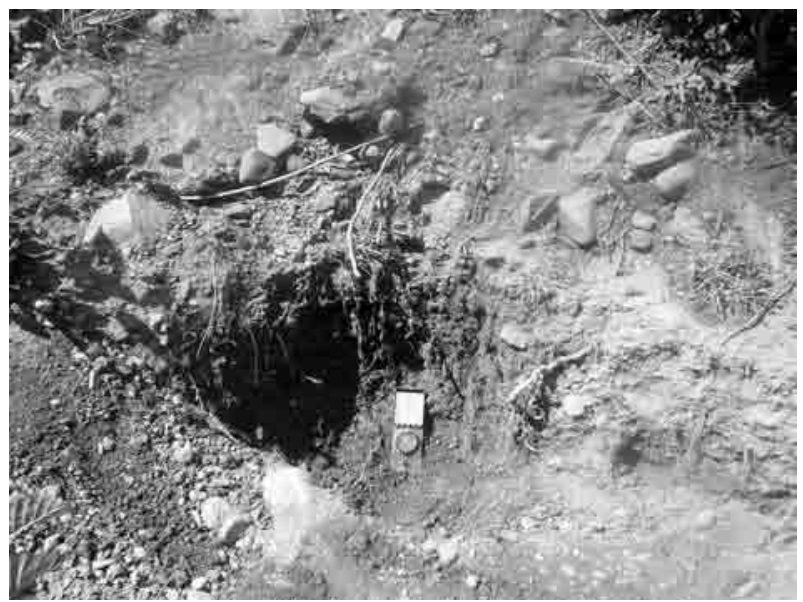

Fig. 10 - The 1922 Moraine Dugout Exposure.

Fig. 10 - Local de amostragem na moreia de 1922. 


\section{Sample \#1}
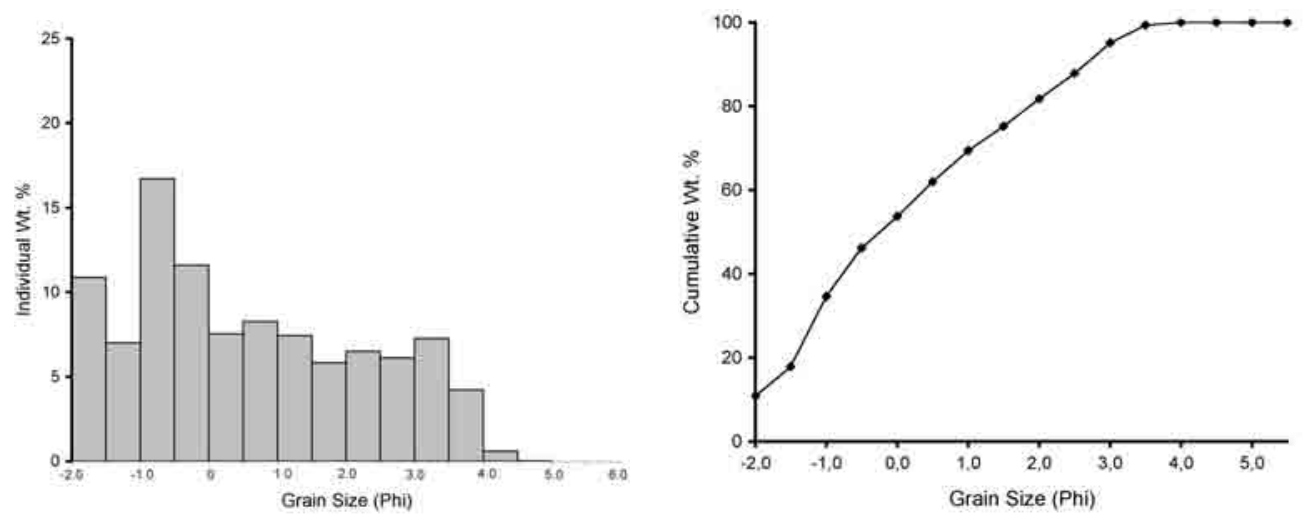

Sample \#2
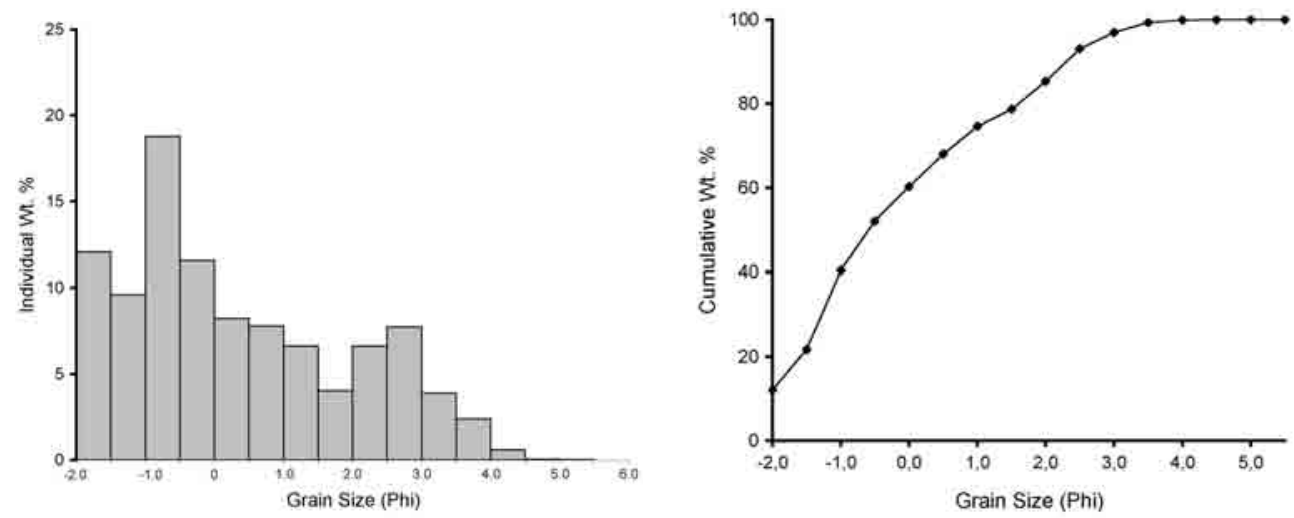

Fig. 11 - Grain size distributions of the 1922 moraine. Exposure 1, Unit 1samples 1 and 2.

Fig. 11 - Distribuição granulométrica na moreia de 1922.

Corte 1,Unidade 1 amostras 1 e 2. 


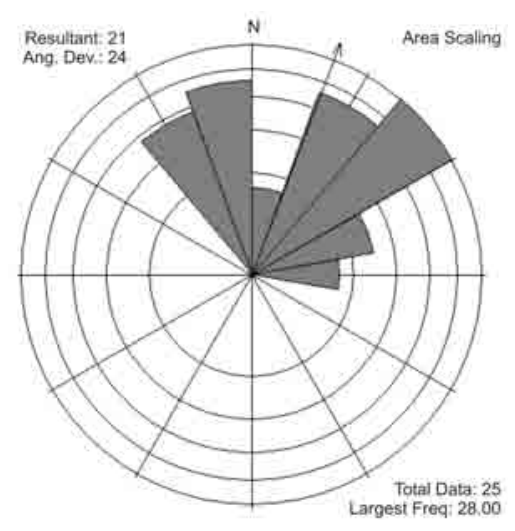

Fig. 12 - Clast orientations in the 1922 moraine. Exposure 1, sample 1.

Fig. 12 - Orientação dos clastos na moreia de 1922 Corte 1, amostra 1.

\section{INTERPRETATION}

The present day moraine morphology and sedimentology in Portage Glacier Valley reveals the presence of two types of glacial tills and moraines that contribute to a very interesting paleo-process history in this glacial valley.

The clast-rich sandy diamicton present on the 1852 moraine is interpreted to be a basal till indicating that this feature is a push moraine representing the LIA maximum advance or standstill position of Portage Glacier until 1852. After this date the glacier started its LIA retreat and may have deposited more sediment into the moraine, which explain the fact that it is the largest glacial moraine in Portage Valley. The assumption that the 1852 moraine is composed mainly of a basal till resides in the presence of well oriented striated clasts in its till fabric and on poorly sorted bi-modal grain size distributions till samples (Dreimanis and Vagners, 1971, 1972). All of these are common characteristics of basal tills (lodgment and deformation tills).

The moderately sorted gray sandy boulder gravel present in the 1900 and 1922 moraines is interpreted to be an ice-marginal deposit (or ablation till) with a mixture of supraglacial and glaciofluvial sediments deposited by slumping and stream sorting processes (Benn and Evans, 1998). The assumption that these features are composed of ablation till resides in the presence of poorly oriented clasts in the till fabric and poorly to moderately sorted unimodal grain size distribution in its till samples (Buller and McManus, 1973). The poorly oriented clasts were deposited by slumping processes common on the supraglacial environment, the moderately sorted sediment is explained by some degree of stream sorting and weathered sediment that exists on the supraglacial environment.

\section{CONCLUSION}

Based on the sedimentology present in these glacial landforms the 1852 terminal moraine is interpreted to be a basal till indicating that this feature is a push moraine representing the LIA maximum advance or standstill position of Portage Glacier until 
1852. The 1900 and 1922 moraines are both interpreted to be ablation moraines representing glacier retreat and moraine building of Portage Glacier from its LIA maximum during 1900 and 1922. Since approximately 1998, Portage Glacier is stable on its current Holocene retracted position at the head of Portage Valley.

\section{REFERENCES}

Benn, D (1994) Fabric shape and the interpretation of sedimentary data. Journal of Sedimentary Research, A64: 910-915.

Benn D, Evans, D (1998) Glaciers and Glaciation. Arnold, London.

Buller A, Mc Manus J (1973) The quartile-deviation/median-diameter relationships of glacial deposits. Sedimentary Geology, 10: 135-146.

Calkin P, Wiles G, Barclay D (2001) Holocene coastal glaciation of Alaska. Quaternary Science Reviews, 20: 449-461.

Crossen K (1992) Guide to the Little Ice Age Landforms and Glacial Dynamics in Portage Valley and Portage Pass, Anchorage. Alaska Geological Society, 46.

Crossen K (1990) Neoglacial history of Portage Glacier, Kenai Mountains, Alaska. Geological Society of America Abstracts with Programs, 22: 7.

Dowdeswell J, Sharp M (1986) Characterization of pebbles fabric in modern terrestrial glaciogenic sediments. Sedimentology, 33: 699-710.

Dreimanis A, Vagners U (1972) The effect of lithology upon texture of till. In Yatsu E, Falconer A (Eds.) Research methods in Pleistocene Geomorphology. Geo Abstracts, Norwich: 66-82.

Dreimanis A, Vagners U (1971) Bimodal distribution of rock and mineral fragments in basal tills. In Goldthwait R P (ed.) Till: a Symposium. Ohio State University Press, Columbus: 237-250.

Easterbrook D (1999) Surface process and landforms. Second Edition. Prentice Hall, New Jersey.

Field W (1975) Mountain glaciers of the northern hemisphere. Hanover, New Hampshire. United States Army Cold Regions Research and Engineering Laboratory, 541.

Field W (1937) Observations on Alaskan coastal glaciers in 1935. Geographical Review, 27: 63-81.

Folk R (1955) Student operator error in determination of roundness, sphericity, and grain size. Journal of Sedimentary Petrology, 25: 297-301.

Folk R (1966) A review of grain size parameters. Sedimentology, 6: 73-93.

Krumbein W (1934) Size frequency distribution of sediments. Journal of Sedimentary Petrology, 4: $65-77$.

Luckman B (1995) Calendar-based, early "Little ice Age" glacier advance at Robson Glacier, British Columbia, Canada. Holocene, 5: 149-159.

Mark D (1973) Analysis of axial orientation data, including till fabrics. Geological Society of America Bulletin, 84: 1369-1374.

Nichols G (1999) Sedimentology and stratigraphy. Blackwell Science Ltd, London.

Seramur K, Powell R, Carlson P (1997) Evaluation of conditions along the ground line of temperate marine glaciers: an example from Muir Inlet, Glacier Bay, Alaska. Marine Geology, 140: 307-327. 
Tarr R, Martin L (1914) Alaska Glacier studies. National Geographic Society, Washington.

Udden J (1898) Mechanical composition of wind deposits. Augustana Library Publication, 1: 69.

Wentworth C (1922) A scale of grades and class terms for clastic sediments. Journal of Geology, 30: $377-392$.

Wiles G (1994) Late Holocene, high resolution glacial chronologies and climate, Kenai Mountains, Alaska. Geological Society of America Bulletin, 106: 281-303.

Wiles G, Barclay D, Calkin P (1999) Tree-ring dated Little Ice Age histories of maritime glaciers from western Prince William Sound, Alaska. Holocene, 9: 163-173.

Wiles G, Post A, Muller E, Molnia B (1999) Dendrochronology and late Holocene history of Bering Piedmont Glacier, Alaska. Quaternary Research, 52: 185-195. 